\title{
Occurrence of Listeria spp. in Ready to Eat Meat Products from Retail Shops of Punjab Region
}

\author{
Ravneet Kaur Walia, Simranpreet Kaur*, Randhir Singh and Pankaj Dhaka
}

School of Public Health and Zoonoses, College of Veterinary Science, Guru AngadDev Veterinary and Animal Sciences University, Ludhiana 141004, India

*Corresponding author

\begin{tabular}{|c|c|}
\hline & A B S T RA C T \\
\hline $\begin{array}{l}\text { Ke y w or d s } \\
\text { L. monocytogenes, } \\
\text { Ready to Eat meat } \\
\text { (RTE) products, } \\
\text { Punjab region }\end{array}$ & \multirow{3}{*}{$\begin{array}{l}\text { In the present study, an attempt was made to detect potentially pathogenic Listeria } \\
\text { monocytogenes along with other Listeria spp. From Ready to Eat meat products from retail } \\
\text { markets of Punjab. A total of } 200 \text { samples of Ready to Eat meat products comprising } 17 \\
\text { chicken seekh, } 26 \text { chicken nuggets, } 52 \text { chicken salami, } 14 \text { chicken sausage, } 6 \text { bacon, } 7 \\
\text { pork sausage, } 10 \text { chicken garlic fingers, } 1 \text { chicken lollipop, } 11 \text { mutton shammi kebab, } 10 \\
\text { chicken shammi kebab, } 13 \text { chicken Tikka, } 1 \text { mutton Tikka, } 32 \text { seekh kebab were } \\
\text { processed. None of the sample found positive for Listeria spp. It was confirmed through } \\
\text { biochemical tests as well as by molecular methods also. Absence of } L \text {. monocytogenes } \\
\text { indicates good sanitation practices in food processing plants and ensures that the food is fit } \\
\text { for consumer consumption in Punjab region. }\end{array}$} \\
\hline Article Info & \\
\hline $\begin{array}{l}\text { Accepted: } \\
12 \text { September } 2020 \\
\text { Available Online: } \\
10 \text { October } 2020\end{array}$ & \\
\hline
\end{tabular}

\section{Introduction}

Listeria monocytogenes is a Gram positive, non sporulating, facultative intracellular exquisitely adaptable environment bacterium with powerful array of regulated virulence factors and it causes one of the serious worldwide food infections called Listeriosis. Listeria monocytogenesis able to form biofilms on various surfaces and this ability is thought to contribute to persistence in the environment and on contact surfaces in the food industry (Zetzmann et al., 2015). L. monocytogenes bacteria can sustain wide ranges of $\mathrm{pH}(4.0-9.5)$ and temperature $(<1-$
45 _C) and are able to survive in the presence of high salt concentrations (up to $10 \% \mathrm{NaCl}$ ) (Liu et al., 2004). This makes the occurrence of L. monocytogenes in ready-to-eat (RTE) foods, such as cooked, raw-cured and drycured salted meat products, of particular concern.

Ready-to-eat (RTE) food products are those foods that do not require further heat treatment to significantly reduce the microbial load before consumption. L. monocytogenes has been isolated from a wide variety of ready-to-eat (RTE) foods and is responsible for several outbreaks of listeriosis linked to 
the consumption of contaminated food stuff such as meat (chevon, mutton, poultry, pork, beef and carabeef) dairy product, processed meat products either raw or partially cooked and vegetables. Even when L. monocytogenes is initially present in small quantities in a foodstuff, it can multiply at varying rates during chilled storage depending on the type of food product, both under aerobic and anaerobic conditions, adapt to disinfectants and adhere to various surfaces. It is of major concern especially in the RTE meat and poultry processing industries as they are ubiquitous organisms and are able to multiply at refrigeration temperatures and under anaerobic conditions. It gets eliminated by the heating process but RTE products may become re-contaminated during production and post-processing steps such as slicing, peeling, and packaging as it is commonly found in the environment of processing plants.

Picture of RTE items bearing the risk of L. monocytogenes is also not cleared. The potential risk of $L$. monocytogenes in different foods has led to recalling of many products like RTE meat products, ice creams, vegetables etc worldwide which causes huge economic losses. Therefore, it is necessary to assess the prevalence of L. monocytogenes in RTE meat products because of the public health implications of potential spread of pathogenic L. monocytogenes. Moreover, in India, the occurrence of Listeria spp. among RTE meat products has not been studied to a large extent. It is in this context that this study was proposed with the following objectives:

To study the prevalence of Listeria species in ready to eat (RTE) meat samples from retail shops of Punjab, India.

Molecular characterization of isolated Listeria species from RTE meat samples.

\section{Materials and Methods}

\section{Calculation of sample size}

The selection of sample size was done according to Simple random sampling method, using the formula given below (Thrusfield, 2007).

$\mathrm{n}=\frac{1.96^{2} \mathrm{P}_{\exp }\left(1-\mathrm{P}_{\exp }\right)}{\mathrm{d}^{2}}$

where, $\mathrm{n}=$ sample size, $\mathrm{P}_{\mathrm{exp}}=$ expected prevalence (as per the prevalence data available), $\mathrm{d}=$ desired absolute precision (d=0.05 at $95 \%$ level of confidence). Listeria spp. were isolated from $15.38 \%$ of sausages (Doijad et al., 2010). $\mathrm{P}_{\exp }$ will be 0.1538 . Employing the above formula, $\mathrm{n}=200$.

\section{Collection of samples}

A total of 200 RTE meat samples were collected from retail shops of Punjab. Samples of different products were collected aseptically in sterile zip lock bags (Table 1). After labeling, samples were immediately transported to laboratory in ice box maintaining cold chain.

\section{Enrichment of samples}

RTE meat sample (25gms) was put in a sterile mortar to which $5-10 \mathrm{ml}$ of autoclaved UVM 1 broth was added. Then with the help of sterile pestle, sample was triturated. After trituration, the entire mixture was transferred to a sterile flask and remaining volume of UVM 1 was added to the flask to make up the final volume to $225 \mathrm{ml}$. The flask was incubated at $30^{\circ} \mathrm{C}$ for $24 \mathrm{hrs}$. After incubation, $1 \mathrm{ml}$ of UVM-I was transferred to $9 \mathrm{ml}$ of UVM 2 which was further incubated at $30^{\circ} \mathrm{C}$ for $24 \mathrm{hrs}$. 


\section{Isolation and identification}

From UVM 2 a loopful of enriched sample was streaked directly onto selective medium polymixinacriflavin lithium chloride ceftazidineaes culinmannitol (PALCAM) agar plate (Hi Media Labs Pvt. Ltd, Mumbai, India) and incubated at $37^{\circ} \mathrm{C}$ for $24-48 \mathrm{hrs}$.

\section{Confirmation of isolates by conventional techniques}

The plates showing diffuse black zones of aesculin hydrolysis with typical green-yellow, glistening, iridescent, pointed colonies having $0.5 \mathrm{~mm}$ diameter were considered as presumptive Listeria spp. Then these colonies were subjected to Gram staining, catalase reaction, tumbling motility at $25^{\circ} \mathrm{C}$, biochemical tests including methyl red-Voges Proskauer (MR-VP) reactions, nitrate reduction, sugar fermentation (rhamnose, xylose, mannitol, lactose, glucose and $\alpha$ methyl- d-mannoside), and in-vitro pathogenicity tests such as phosphatidylinositol-specific phospholipase C (PI-PLC) activity on Agar Listeria according to Ottaviani and Agosti (ALOA), haemolysis on 7\% sheep blood agar and CAMP test with Staphylococcus aureus and Rhodococcus equi.

Conventional PCR based detection of Listeria spp. and species L. monocytogenes

After performing conventional biochemical tests for detection of Listeria spp. and sugar fermentation, additional confirmation was done by molecular technique especially, PCR. The PCR reaction was carried out for amplification of Listeria targeting genus specific gene, putative phosphoribosyl pyrophosphate synthetase (prs) and $L$. monocytogenes specific, haemolysin (hlyA) gene. The PCR for amplification forprs and hlyA gene was carried out in a total reaction volume of $25 \mu \mathrm{l}$ containing $12.5 \mu \mathrm{l}$ Master mix (EmeraldAmp®GT PCR Master Mix, Takara Bio Product), $0.5 \mu \mathrm{l}$ of $10 \mathrm{pmol} / \mu \mathrm{l}$ of primer set containing forward and reverse primer, $2 \mu \mathrm{l}$ of DNA template and rest sterilised nuclease free water to make up the reaction volume. The reaction mixture was vortexed and then flash spun in a micro centrifuge to settle the reaction mixture at the bottom. The DNA amplification reaction was performed in Mastercycler Gradient Thermocycler (Eppendroff, Germany) with pre-heated lid.

The cycling conditions for prs gene included an initial denaturation of DNA at $94^{\circ} \mathrm{Cfor} 1$ minute followed by 35 cycles each of denaturation at $94^{\circ} \mathrm{C}$ for 30 seconds, annealing at $53^{\circ} \mathrm{C}$ for 45 seconds and extension at $72^{\circ} \mathrm{C}$ for 45 seconds followed by final extension at $72^{\circ} \mathrm{C}$ for 2 minutes and finally reaction hold at $4^{\circ} \mathrm{C}$.

The cycling conditions for hlyA gene targeting PCR included an initial denaturation of DNA at $94^{\circ} \mathrm{C}$ for 2 minutes followed by 35 cycles each of denaturation at $94^{\circ} \mathrm{C}$ for 30 seconds, annealing at $53^{\circ} \mathrm{C}$ for 1 minute and extension at $72^{\circ} \mathrm{C}$ for 1 minute 30 seconds followed by final extension at $72^{\circ} \mathrm{C}$ for 10 minutes and finally reaction hold at $4^{\circ} \mathrm{C}$. The standard strain of L. monocytogenes (ATCC 19115) was used as positive control, while nuclease free water as negative control. The amplified PCR products were analysed by using agarose gel electrophoresis and the bands in the gel were visualised by Gel Documentation System (Syngene, USA). The nucleotide sequences used in primer sets are listed in table 2.

\section{Real Time PCR for detection of Listeria sp.}

Real time PCR based detection of Listeria spp. and $L$. monocytogenes was done by targeting prs and hly A gene respectively, the 
primer sequence for the same is mentioned in table 2. The qPCR amplification was carried out in LightCycler 96 Roche (Germany). The reaction was carried out in $25 \mu \mathrm{l}$ reaction mixture containing $12.5 \mu \mathrm{l}$ of Power SYBR ${ }^{\circledR}$ Green PCR master mix (Thermo Fisher Scientific, UK), $1.0 \mu \mathrm{l}$ of $10 \mathrm{pmol} / \mu \mathrm{l}$ of each primer set containing forward and reverse primers, $2 \mu \mathrm{l}$ of DNA template and $8.5 \mu \mathrm{l}$ sterilised nuclease free water to make up the reaction volume. After carefully adding the components, strips were briefly spun and loaded on to the Roche thermocycler.

The cycling conditions for qPCR included a single cycle of initial denaturation at $94^{\circ} \mathrm{C}$ for 5 minute followed by 40 cycles each of denaturation at $94^{\circ} \mathrm{C}$ for 30 seconds, annealing and extension at $60^{\circ} \mathrm{C}$ for 30 seconds. The final result of each reaction was expressed in threshold cycle (ct). The qPCR software (LightCycler® 96 SW 1.1) was used for data analysis. The qPCR monitored the fluorescence of reaction mixtures and recorded the cycle number at which fluorescence crossed a specific threshold value and reached the exponential phase of amplification, which was designated as threshold cycle (Ct). The nucleotide sequences used in primer sets are listed in table 2 .

\section{Results and Discussion}

A total of 200 samples of Ready to Eat meat products comprising 17 chicken seekh, 26 chicken nuggets, 52 chicken salami, 14 chicken sausage, 6 bacon, 7 pork sausage, 10 chicken garlic fingers, 1 chicken lollipop, 11 mutton shammi kebab, 10 chicken shammi kebab, 13 chicken Tikka, 1 mutton Tikka, 32 seekh kebab were processed.

The suspected colonies were subjected to biochemical tests, in-vitro pathogenicity tests and also they were subjected to qPCR and conventional PCR. None of the sample was found positive for Listeria spp. Therefore, zero percent prevalence of $L$. monocytogenes was found from ready to eat meat products.

Table.1 Collection of Ready to Eat meat products from Punjab

\begin{tabular}{|c|l|c|}
\hline Sr. No. & Name of the sample & Number of samples \\
\hline $\mathbf{1}$ & Chicken Seekh & 17 \\
\hline $\mathbf{2}$ & Chicken nuggets & 26 \\
\hline $\mathbf{3}$ & Chicken salami & 52 \\
\hline $\mathbf{4}$ & Chicken sausage & 14 \\
\hline $\mathbf{5}$ & Bacon & 6 \\
\hline $\mathbf{6}$ & Pork sausage & 7 \\
\hline $\mathbf{7}$ & Chicken Garlic Fingers & 10 \\
\hline $\mathbf{8}$ & Chicken Lollipop & 1 \\
\hline $\mathbf{9}$ & Mutton Shammi Kebab & 11 \\
\hline $\mathbf{1 0}$ & Chicken Shammi Kebab & 10 \\
\hline $\mathbf{1 1}$ & Chicken Tikka & 13 \\
\hline $\mathbf{1 2}$ & Mutton Tikka & 1 \\
\hline $\mathbf{1 3}$ & Seekh Kebab & 32 \\
\hline Total & & 200 \\
\hline
\end{tabular}


Table.2 Nucleotide sequences of primer sets used for detection of Listeria spp. L. monocytogenes in the study

\begin{tabular}{|c|c|c|c|c|}
\hline Primer Name & \multicolumn{2}{|r|}{ Primer Sequence } & Product & Reference \\
\hline \multirow{2}{*}{$\begin{array}{c}\text { Prs-2-deg } \\
\text { (Listeria. Spp) } \\
\text { For qPCR }\end{array}$} & $\begin{array}{c}\text { Forwar } \\
\mathrm{d}\end{array}$ & 5'- ATTTTCTCGCTAAATTCTAATCGTG- 3' & \multirow[t]{2}{*}{$60 \mathrm{bp}$} & \multirow{2}{*}{$\begin{array}{l}\text { Barbau- } \\
\text { Piednoir } \\
\text { et al }(2013)\end{array}$} \\
\hline & Reverse & 5'- CAATACCWACTTCTTTCGCAATCTC- 3' & & \\
\hline \multirow{2}{*}{$\begin{array}{c}\text { hylA-146-deg-tronc } \\
\text { (L. monocytogenes) } \\
\text { For qPCR }\end{array}$} & $\begin{array}{c}\text { Forwar } \\
\mathrm{d}\end{array}$ & 5’- AAATCTGTCTCAGGYGATGT-3' & \multirow[t]{2}{*}{$103 \mathrm{bp}$} & \multirow[t]{2}{*}{$\begin{array}{l}\text { Hough et al } \\
\quad(2002)\end{array}$} \\
\hline & Reverse & $\begin{array}{c}\text { 5'- } \\
\text { CGATGATTTGAACTTCATCTTTTGC-3, }\end{array}$ & & \\
\hline \multirow{2}{*}{$\begin{array}{c}\text { Prs } \\
\text { (Listeria spp.)for } \\
\text { conventional PCR }\end{array}$} & Forward & $\begin{array}{c}5^{\prime}- \\
\text { GCTGAAGAGATTGCGAAAGAAG-3' }\end{array}$ & \multirow[t]{2}{*}{$370 \mathrm{bp}$} & \multirow[t]{2}{*}{$\begin{array}{l}\text { Doumithet al., } \\
2004\end{array}$} \\
\hline & Reverse & $\begin{array}{c}5^{\prime} \text { - } \\
\text { CAAAGAAACCTTGGATTTGCGG-3, }\end{array}$ & & \\
\hline \multirow{2}{*}{$\begin{array}{c}\text { hlyA } \\
(L . \\
\text { monocytogenes }) \\
\text { for conventional PCR }\end{array}$} & Forward & $\begin{array}{c}5^{\prime}- \\
\text { GCAGTTGCAAGCGCTTGGAGTGAA-3, }\end{array}$ & \multirow[t]{2}{*}{$56 \mathrm{bp}$} & \multirow{2}{*}{$\begin{array}{r}\text { Pazaik } \\
\text {-Domanskaet } \\
\text { al.(1999) }\end{array}$} \\
\hline & Reverse & $\begin{array}{c}5^{\prime} \text { - } \\
\text { GCAACGTATCCTCCAGAGTGATCG-3' }\end{array}$ & & \\
\hline
\end{tabular}

In India, Doijadet al (2010) conducted study on 52 pork sausages and found that $15.38 \%$ samples were contaminated with Listeria spp. Results of our study were similar to Abdelgadir et al., (2009) in which prevalence of meat was $1.2 \%$, and prevalence of sausages and frankfurters was only $0.4 \%$ only. Osaili et al., (2014) revealed that overall prevalence of L. monocytogenes harboured from RTE chicken and RTE beef products was found to be $2 \%$, with $2.7 \%$ and $1.5 \%$ prevalence in RTE chicken and beef products, respectively.

In contrast to our study, some of the researchers found that prevalence of $L$. monocytogenes in RTE meats were quiet high. Osaili et al., (2010) found 50\% of the samples of RTE meat products were contaminated with Listeria spp. Whereas, Alsheikh et al., (2012) revealed that 38\% of samples of retail ready to eat chicken products were contaminated with Listeria spp. A study was conducted in which effects of lactate and acetate were studied and they concluded that presence of lactate and acetate in RTE meat products were associated with low occurrence of L. monocytogenes in RTE meats (Ahmed et al., 2015).Essential oils of various spices used in the preparation of ready to eat foods are having antimicrobial roles. A research on carvacrol and nisinstated that they act in synergism in killing $L$. monocytogenes through various pathways (Charklam et al.,). It was also found that essential oils of conifers were having anti-listerial properties (Mourey et al., 2020). Moreover, hygiene and sanitation also plays a major role in RTE meat products contamination during post processing including packaging, handling or also due to collective handling of raw as well as processed foods on the same table.

Good Sanitation and hygiene practices followed in the processing and manufacturing unit also play a vital role in the reduction of the microbial load in the final product.

In conclusion, listeria spp. could not be detected in RTE meat products, indicating that such products undergo hygienic processing and are fit for consumption in Punjab region of India. 


\section{References}

Abdelgadir A M, Srivastava K K and Reddy P G. 2009. Detection of Listeria monocytogenesin ready-to-eat meat products. American Journal of Animal and Veterinary Sciences4(4): 101-07

Ahmed, O. M., Pangloli, P., Hwang, C. A., Zivanovic, S., Wu, T., D'Souza, D., and Draughon, F. A. (2015). The occurrence of Listeria monocytogenes in retail ready-to-eat meat and poultry products related to the levels of acetate and lactate in the products. Food Control, 52, 43-48.

Alsheikh, A. D. I., Mohammed, G. E., \&Abdalla, M. A. (2013).Isolation and identification of Listeria monocytogenes from retail broiler chicken ready to eat meat products in Sudan. International Journal of Animal and Veterinary Advances, 5(1), 9-14.

Barbau-Piednoir, E., Botteldoorn, N., Yde, M., Mahillon, J., and Roosens, N. H. (2013). Development and validation of qualitative SYBR ${ }^{\circledR}$ Green real-time PCR for detection and discrimination of Listeria spp. and Listeria monocytogenes. Applied Microbiology and Biotechnology, 97(9), 4021-4037.

Churklam, W., Chaturongakul, S., Ngamwongsatit, B., and Aunpad, R. (2020). The mechanisms of action of carvacrol and its synergism with nisin against Listeria monocytogenes on sliced bologna sausage. Food Control, 108, 106864.

Doijad, S. P., Vaidya, V., Garg, S., Kalekar, S., Rodrigues, J., D'costa, D. and Barbuddhe, S. B. (2010). Isolation and characterization of Listeria species from raw and processed meats.

Doumith, M., Buchrieser, C., Glaser, P., Jacquet, C., and Martin, P. (2004). Differentiation of the major Listeria monocytogenesserovars by multiplex PCR. Journal of clinical microbiology, 42(8), 3819-3822.

Hough, A. J., Harbison, S. A., Savill, M. G., Melton, L. D., and Fletcher, G. (2002). Rapid enumeration of Listeria monocytogenes in artificially contaminated cabbage using real-time polymerase chain reaction. Journal of food protection, 65(8), 1329-1332.

Liu, D., Lawrence, M. L., Austin, F. W., \& Ainsworth, A. J. (2007).A multiplex PCR for species-and virulence-specific determination of Listeria monocytogenes. Journal of Microbiological Methods, 71(2), 133140.

Mourey, A., \&Canillac, N. (2002).AntiListeria monocytogenes activity of essential oils components of conifers. Food control, 13(4-5), 289-292.

Osaili, T. M., Alaboudi, A. R., and Nesiar, E. A. (2011). Prevalence of Listeria spp. and antibiotic susceptibility of Listeria monocytogenes isolated from raw chicken and ready-to-eat chicken products in Jordan. Food Control, 22(3-4), 586-590.

Osaili, T. M., Al-Nabulsi, A. A., Shaker, R. R., Jaradat, Z. W., Taha, M., AlKherasha, M., and Holley, R. (2014). Prevalence of Salmonella serovars, Listeria monocytogenes, and Escherichia coli O157: H7 in Mediterranean ready-to-eat meat products in Jordan. Journal of food protection, 77(1), 106-111.

Thrushfield, M. (2007). Veterinary Epidemiology: Surveys.

Zetzmann, M., Okshevsky, M., Endres, J., Sedlag, A., Caccia, N., Auchter, M. and Riedel, C. U. (2015). DNasesensitive and-resistant modes of biofilm formation by Listeria monocytogenes. Frontiers in microbiology, 6, 1428. 


\section{How to cite this article:}

Ravneet Kaur Walia, Simranpreet Kaur, Randhir Singh and Pankaj Dhaka. 2020. Occurrence of Listeria spp. in Ready to Eat Meat Products from Retail Shops of Punjab Region. Int.J.Curr.Microbiol.App.Sci. 9(10): 1645-1651. doi: https://doi.org/10.20546/ijcmas.2020.910.198 